\title{
Analisa Organoleptik dan Mikrobiologi AMDK dan AMIU yang Dijual Sekitar Kampus UMKU
}

\author{
Yunita Rusidah', Lailatul Farikhah ${ }^{1}$ \\ ${ }^{1}$ Universitas Muhammadiyah Kudus \\ E-mail: yunita_bio04035@yahoo.co.id
}

\begin{abstract}
This study is intended to find the quality of bottled drinking water (AMDK) and drinking water (AMIU) sold around University of Muhammadiyah Kudus, in terms of organoleptic and microbiological parameters in drinking water according to SNI 01-3554-2006 and PMK No. 492 of 2010. The test is carried out using 10 sample of drinking water. They are 7 sample of AMDK (Ades, Airmu, Aqua, Cleo, Crystalin, Le mineral and Vit) and 3 sample of AMIU (Pasuruhan, Prambatan and Purwosari depots). The research consists of organoleptic and mikrobiologi (TPC, presence of E. coli and total coliform). The results of research shows that the organoleptik of all samples is in normal condition. Whereas, microbiologically, the TPC results before dilution were only Cleo and Ades which were suitable for consumption because they were absent from bacterial contamination. While the TPC results after dilution, testing the difference between E. Coli and Total coliform resulted in 7 samples of bottled drinking water which were safe and feasible as drinking water according to SNI 01-3553-2006 and 3 samples AMIU does not fulfil PMK No. 492/2010, as drinking water requirements.
\end{abstract}

Keywords: AMDK, AMIU, Organoleptic Quality, Microbiology

\section{Abstrak}

Penelitian ini bertujuan mengetahui kualitas air minum dalam kemasan (AMDK) dan air minum isi ulang (AMIU) yang dijual di sekitar kampus Universitas Muhammadiyah Kudus, ditinjau dari parameter organoleptik dan mikrobiologis pada air minum sesuai SNI 01-3554-2006 dan PMK no 492 tahun 2010. Pengujian dilakukan mengunakan 10 sampel air mineral, meliputi 7 AMDK (Ades, Airmu, Aqua, Cleo, Crystalin, Le mineral dan Vit) dan 3 sampel AMIU diambil dari depot air minum isi ulang disekitar kampus yaitu dari depot AMIU Pasuruhan, Prambatan dan Purwosari. Penelitian dilakukan di PT Sariguna Primatirta Kudus, yang merupakan pabrik AMDK di kota Kudus, yang memiliki persyarataan pengujian AMDK. Pengujian yang dilakuan meliputi organoleptik dan mikrobiologi yaitu TPC, keberaadaan E.coli dan Total Coliform. Hasil penelitian didiskripsikan bahwa hasil organoleptik dari 10 sampel menghasilkan kondisi normal. Namun secara mikrobiologis hasil TPC sebelum pengeceran hanya Cleo dan Ades yang laik dikonsumsi karena aman dari kontaminasi bakteri. Sedangkan Hasil TPC setelah pengenceran, pengujian kebedaan E.Coli dan Total coliform menghasilkan 7 sampel AMDK aman dan laik sebagai air minum sesuai SNI No.01-3553 tahun 2006 dan 3 sample AIMU tidak memenuhi PMK no 492 tahun 2010, sebagai persyaratan air minum.

Kata kunci: AMDK,AMIU, Kualitas organoleptik, Mikrobiologis

\section{Pendahuluan}

Air merupakan materi yang sangat penting dalam kehidupan manusia, untuk kelangsungan hidup. Manusia tentu tidak akan terlepas dari kebutuhan akan air bersih terutama air minum. Oleh karena itu, kualitas air untuk air minum harus mendapatkan perhatian utama. Air yang digunakan untuk air minum harus memenuhi berbagai persyaratan diantaranya secara fisik, air tidak berwarna, berasa dan berbau. Selain itu, air minum yang dikonsumsi harus higienis dan kandungan mikroba di dalamnya 
tidak melewati ambang batas yang ditetapkan SNI maupun pe raturan menteri kesehatan. Air minum adalah air yang layak untuk dikonsumsi, namun sekarang pengadaan air minum menjadi semakin sulit, sedangkan konsumen menuntut tersedianya air minum yang mudah didapat. Sofa (2010), Tuntutan itu terjawab dengan hadirnya air minum dalam kemasan (AMDK) di pasaran. Air minum jenis ini dapat langsung dikonsumsi karena berasal dari sumber yang aman dan telah melalui proses pengolahan dan pengemasan yang memenuhi standar mutu.

Kepmenkes RI No. 907 /Menkes / SK / VII / 2002, menjelaskan bahwa air minum adalah air melalui proses pengolahan maupun tanpa proses pengolahan yang memenuhi syarat dan dapat langsung diminum. Air minum harus memenuhi persyaratan fisik, kimia, maupun bakteriologis supaya tetap sehat. Departemen Kesehatan Republik Indonesia (2002), kriteria kualitas air secara mikrobiologis, melalui Keputusan Menteri Kesehatan No. 907 tahun 2002 bahwa air minum tidak diperbolehkan mengandung bakeri coliform dan Eschericia coli (Pratiwi, 2014). Standart Nasional Indonesia (SNI) No. 3553:2015, menetapkan 34 parameter sebagai persyaratan kualitas AMDK, fisik, kimia dan biologi. Parameter persyaratan mikrobiologi dapat dianalisa melalui uji bakteriologi yang meliputi Total Coliform, ALT, dan Pseudomonas aeruginosa (Agustini, 2017).

Konsumsi air minum dalam kemasan (AMDK) di Indonesia dalam beberapa tahun terakhir ini mengalami peningkatan. Kondisi ini ditunjang oleh semakin buruknya kondisi air tanah di beberapa kota besar di Indonesia seperti Jakarta, Surabaya dan Semarang. Tingkat ketergantungan masyarakat pada AMDK semakin tinggi karena minuman ini sudah menjadi kebutuhan primer bagi masyarakat. Pada tahun 2013 konsumsi Air Minum Kemasan di Indonesia mencapai angka 15,3 miliar liter dimana angka ini lebih besar dari tahun 2012 yang mencapai angka 13,8 miliar liter (Deril, 2014).

Saat ini banyak sekali bermunculan produsen Air Minum Dalam Kemasanan, seiring permintaan masyarakat yang selalu mengalami peningkatan setiap tahunnya. Banyaknya produk air minum dalam kemasan di pasaran, sehingga masyarakat dapat memilih mulai dari harga sangat murah hingga mahal, dapat memilih pula dari merk kurang terkenal sampai merek terkenal. Selain itu, masyarakat mempunyai pilihan lain untuk mendapatkan air minum yang baik ditengah-tengah semakin mahalnya harga air minum dalam kemasan (AMDK) maka beberapa masyrakat di daerah perkotaan memilih untuk memenuhi kebutuhan air minum dari depot air minum isi ulang (AMIU) yang pada saat ini telah berkembang pesat di seluruh daerah di Indonesia.

Konsumsi air minum dalam kemasan dan air minum isi ulang di Kudus, khususnya wilayah dekat dengan kampus Universitas Muhammadiyah Kudus yang didominasi anak-anak pelajar atau mahasiswa kos mengalami peningkatan hal ini dikarenakan semakin modernisasi yang menuntut kepraktisan kebutuhan hidup menyebabkan pergeseran kebiasaan dan perilaku manusia. Dewasa ini hampir semua lapisan masyarakat telah beralih ke Air Minum Dalam Kemasan (AMDK) dan Air Minum Isi Ulang (AMIU) dan untuk konsumsi sehariharinya. Rahayu (2010), menjelaskan dengan adanya peningkatan permintaan pasar terhadap AMDK menuntut produsen memberikan inovasi baru dalam penyediaan, pengolahan maupun pemasarannya. Namun kendalanya adalah lemahnya pengawasan 
produk makanan dan minuman di Indonesia yang dapat membuka peluang pemalsuan berbagai merek AMDK, pembuatan AMDK tanpa ijin ataupun penjualan Air isi ulang tanpa ijin yang berwenang. Semua kecurangan produsen tersebut tentunya akan membawa dampak terhadap kesehatan (Rahayu, 2010). Banyak depot air minum yang belum berijin sehingga dari segi kebersihan sanitasi maupun instalasi dan sumber airnya meragukan. Oleh karena itu penelitian ini dilakukan untuk mengetahui kualitas AMDK dan AMIU baik secara organoleptik maupun kualitas mikrobiolgisnya.

\section{Metode Penelitian}

Materi yang digunakan air minum dalam kemasan dan air minum isi ulang yang dijual di sekitar kampus Universitas Muhammadiyah Kudus terdiri dari 7 merk yaitu Ades, Airmu, Aqua, Cleo, Crystaline, Le Mineral dan Vit. Air minum isi ulang dari 3 depot air minum isi ulang yaitu depot air minum isi ulang Prambatan, depot air minum isi ulang Pasuruhan dan depot Purwosari. Media PCA, media CCA, aquades, air RO steril. Aquades, air RO,

Peralatan yang digunakan petri dish, kertas saring $0,45 \mu$, mikro pipet dan tip, corong holder, alat vakum, timbangan analitik, LAF, mikropipet, magnetik stirer, autoklaf, oven, hot plate, colony counter, semua peralatan sudah dikalibrasi secara kontinyu sama pihak terkait.

Desain penelitian yang digunakan dalam penelitian ini adalah Deskriptif. Metode deskriptif merupakan metode yang bertujuan untuk memaparkan atau menjelaskan peristiwa yang berlangsung saat proses penelitian yang tanpa menghiraukan sesudah ataupun sebelumnya (Lestari, dkk, 2018). Peneliti menggunakan jenis desain penelitian deskriptif karena hanya ingin melihat bagaimana kualitas produk air minum dalam kemasan (AMDK) dan air minum isi ulang (AMIU) yang dijual disekitar Universitas Muhammadiyah Kudus telah memenuhi syarat sebagai air minum layak konsumsi atau belum sesuai dengan syarat yang ditentukan oleh Standart Nasional Indonesia (SNI) No. 3553:2015.

Penelitian dilakukan di Laboratorim PT Sariguna Primatirta Kudus, yang merupakan pabrik AMDK yang ada di kota Kudus, yang memiliki laboratorium dengan persyaratan pengujian AMDK. Sampel air diambil disekitar kampus Univeritas Muhammadiyah Kudus, untuk AMDK dibeli, sampel AIMU diambil dari depot menggunakan galon yang steril dan langsung dibawa ke laboratorium untuk dilakukan pengujian tidak lebih dari 24 jam setelah pengambilan sampel. Penelitian ini dilakukan pada bulan Februari 2021.

\section{Cara Kerja}

\section{Uji organoleptik}

Uji organoleptik merupakan uji sensoridengan menggunakan indera manusia sebagai alat utama untuk pengukuran daya penerimaan terhadap produk. Peranan uji ini penting dalam penentuan kualitas yaing meliputi bau, rasa dan warna. Pengujian organoleptik dapat memberikan indikasi kebusukan, kemunduran mutu dan kerusakan lainnya dari produk. Air minum yang ideal adalah air yang tidak berbau, tidak berasa dan tidak berwarna.

\section{Uji Mikrobiologis}

Pengujian ALT (Angka LempenganTotal) atau TPC (Total Plate Count)

Preparasi media

Sebanyak 2,25 gram PCA $+100 \mathrm{ml}$ Aquades diautoklaf selama 15 menit pada suhu $121^{\circ} \mathrm{C}$ 


\section{Analisa TPC}

Satu $\mathrm{ml}$ sampel diambil dengan menggunakan tip, dituang di dalam petri dish, kemudian dituangkan media PCA yang sudah disterilkan, setelah media padat dimasukan dalam inkubator pada suhu $37^{\circ} \mathrm{C}$ selama 24 jam. Kemudian dianalisa hasilnya setelah 24 jam.

Dihitung koloni pada cawan perti dengan koloni antara 30-300. Cawan diletakkan secara terbalik lalu dihitung menggunakan alat Colony Counter dengan alat perhitungan mekanis ditangan, Jumlah koloni dihitung dari baris keatas secara horizontal, pada baris di bawahnya dan seterusnya (TPC sebelum pengenceran)

Selanjutnya dilakukan pengenceran $10^{-1}$, $10^{-2}, 10^{-3} \mathrm{dst}$ dengan cara $1 \mathrm{ml}$ sample yang diuji dipindahkan dengan pipet steril kedalam larutan $9 \mathrm{ml}$ aquades untuk mendapatkan pengenceran $10^{-2}$. Lakukan hal yang sama pada pengenceran $10^{-3}$ dst. Selanjutnya $1 \mathrm{ml}$ hasil pengenceran diinokulasikan pada cawan petri kosong. Kemudian dituangkan media agar PCA cair (metode pour plate). Campurkan media dengan sampel dengan memutar cawan petri mengikuti pola angka delapan. Inkubasi sampel pada suhu $37^{\circ} \mathrm{C}$ selama 24 jam. Hasil pertumbuhan koloni pada media agar. Jumlah TPC dihitung dengan menggunakan Coloni Counter terakhir didapatkan hasil TPC setelah pengenceran.

\section{Identifikasi Bakteri Escherichia danAnalisa Coliform (metode filtrasi) \\ - Media CCA \\ - $\quad$ Kertas saring whatman 0,45 $\mu$ \\ - $\quad$ Air steril (Air RO yang disterilkan)}

Prosedur nya sebanyak 2,65 gram ditambahkan $100 \mathrm{ml}$ air RO steril dan dihomogenkan dengan stirer dengan pemanasan pada suhu $270{ }^{\circ} \mathrm{C}$ dengan hot plate selama 30 menit. Setelah itu media CCA cair dituang ke petri dish dan didinginkan sampai padat. Kemudian sampel sebanyak $200 \mathrm{ml}$ dituang pada corong holder yang sebelumnya telah diisi kertas saring 0,45 $\mu$. Setelah itu divakum sampai sampel habis.
Kertas saring bekas fitrasi ditanam diatas media CCA yang sudah padat diinkubasi pada suhu $37{ }^{\circ} \mathrm{C}$ selama 24 jam kemudian dianalisa berdasarkan perbedaan warna yang mucul dikertas saring. Jika yang muncul warna hijau sampai biru tua menandakan adanya kontaminasi $E$. coli dan jika warna merah tua/muda atau ungu itu menandakan coliform. Total coliform adalah gabungan dari warna hijau-biru dan ungu.

\section{Hasil dan Pembahasan}

\section{Uji Organoleptik}

Uji organoleptik merupkan pengujan dengan indera melalui rasa dengan indera pengecapan, warna dengan indera penglihatan, dan bau dengan indera pembau menghasilkan kondisi normal tidak ada permasalahan organoleptik dari kesepuluh sampel yang diujikan. Tiga puluh orang tester mengatakan tidak ada perbedaan dari segi organoleptik bahkan mereka tidak bisa merasakan perbedaan antara dua jenis dan merknya, hasilnya semua sama baik dari rasa, warna maupun bau baik produk air minum dalam kemasan (AMDK) maupun air minum isi ulang (AMIU).

\section{Uji Mikrobiologi}

Hasil TPC sebelum pengeceran didapatkan, untuk air minum dalam kemasan (AMDK) hanya sampel Cleo dan Ades yang aman tidak ditumbuhi bakteri. Sedangkan untuk sampel Le mineral ada 1 koloni besar, vit terdapat 2 koloni, airmu 3 koloni, Crystalin 7 koloni dan aqua 16 koloni. Jadi yang memenuhi persyaratan sebagai air minum konsumsi hanya Cleo dan Ades. Sedangkan untuk dari depot air minum isi ulang (AIMU) didapatkan hasil depot prambatan 47 koloni dan dua depot lainnya yaitu depot pasuruhan dan depot purwosari hasilnya sangat banyak koloni sehingga dikatogorikan TBUD (tidak bisa untuk dihitung). 
Gambar 1. Hasil pengujian TPC sebelum pengenceran

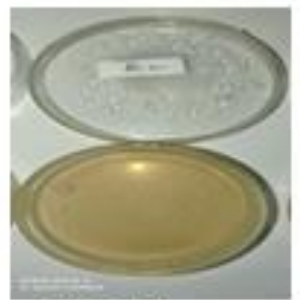

TPC Airmu

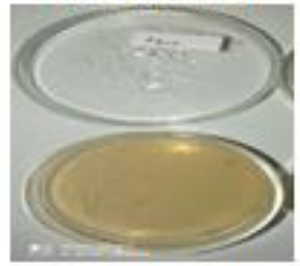

TPC Aqua

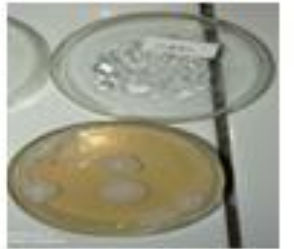

TPC Crystalin

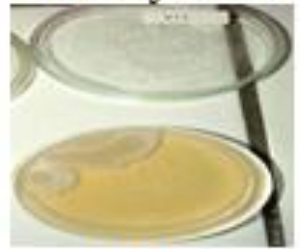

TPC VIT

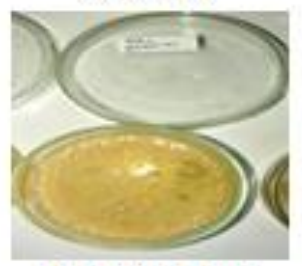

TPC Depot

Purwosari

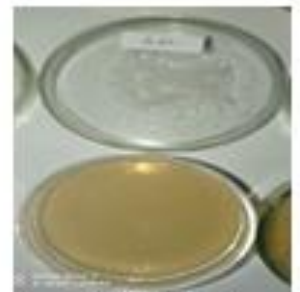

TPC Ades

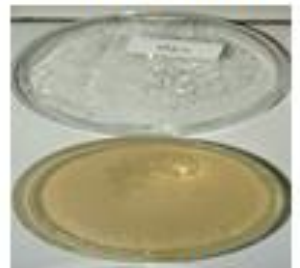

TPC Cleo
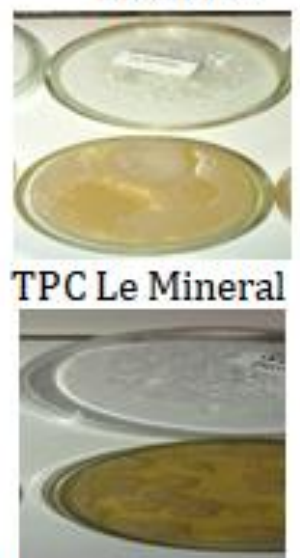

TPC Depot Prambatn

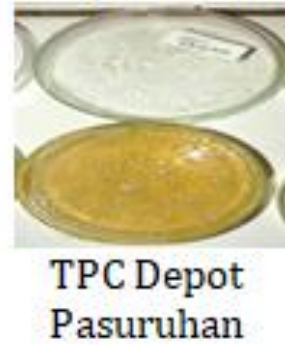

Setelah dilakukan pengeceran bertingkat didapatkan hasil seperti tabel diatas yaitu semua AMDK aman dari kontaminasi bakteri sehingga memenuhi persyaratan mikrobiologi sesuai SNI No.01-3553 tahun 2006 sebagai air minum langsung konsumsi. Namun untuk hasil TPC dari depot AMIU masih tidak memenuhi persyataran sebagai air minum karena didapatkan hasil depot Prambatan $4 \mathrm{xl0}^{2}$ koloni, depot Pasuruhan terdapat koloni bakteri $174 \mathrm{xl0}^{2}$ dan yang paling besar adalah depot Purwosari yaitu terdapat koloni bakteri $193 \times 10^{2}$ sehingga dapat disimpulkan bahwa ketiga depot AMIU tidak memenuhi persyaratan sebagai air minum yaitu dibawah $1,0 \mathrm{x} \quad 10^{2}$. Hal ini mungkin dikarenakan air berasal dari sanititasi instalasi depot air yang tidak memperhatikan sanitisasi yang baik baik dari tandon air penampungan maupun dari instalasi pipa depot. Penyebab lain dimungkinan juga dikarenakan sumber air nya yaitu berasal dari PABS (perusahaan air bersih swasta) dimungkinan tangki pengangkutan kurang hyginis. (Sekarwati, 2016) Depot purwosari paling besar kontaminan bakteri dimungkinan karean letak depotnya menghadap langsung sinar matahari dalam waktu yang lama dapat mengakibatkan migrasi senyawa dari instalasi depot atau tandon yang terpapar sinar matahari ke dalam air sample menyebabkan bahaya bagi peminumnya (Conant, 2021).

Hasil TPC sebelum pengeceran didapatkan, dapat disajikan pada tabel 1 .

Tabel 1. Hasil pengujian TPC sebelum pengenceran

\begin{tabular}{llll}
\hline Sampel & TPC & Syarat & Ket \\
\hline Cleo & 0 & 0 & MS \\
Le Mineral & 1 & 0 & TMS \\
VIT & 2 & 0 & TMS \\
Aqua & 16 & 0 & TMS \\
Airmu & 3 & 0 & TMS \\
Ades & 0 & 0 & MS \\
Crystalin & 7 & 0 & TMS \\
Depot Pasuruhan & TBUD & 0 & TMS \\
Depot Prambatan & 47 & 0 & TMS \\
Depot Purwosari & TBUD & 0 & TMS \\
\hline
\end{tabular}

Keterangan :

TMS (Tidak Memenuhi Syarat), MS (Memenuhi Syarat) 
Tabel 2. Hasil pengujian TPC setelah pengenceran

\begin{tabular}{lcll}
\hline Sampel & TPC & SNI & Ket \\
\hline Cleo & 0 & $1,0 \times 10^{2}$ & MS \\
Le Mineral & 0 & $1,0 \times 10^{2}$ & MS \\
VIT & 0 & $1,0 \times 10^{2}$ & MS \\
Aqua & 0 & $1,0 \times 10^{2}$ & MS \\
Airmu & 0 & $1,0 \times 10^{2}$ & MS \\
Ades & 0 & $1,0 \times 10^{2}$ & MS \\
Crystalin & 0 & $1,0 \times 10^{2}$ & MS \\
$\begin{array}{l}\text { Depot } \\
\text { Pasuruhan }\end{array}$ & $174 \times 10^{2}$ & $1,0 \times 10^{2}$ & TMS \\
$\begin{array}{l}\text { Depot } \\
\text { Prambatan }\end{array}$ & $4 \times 10^{2}$ & $1,0 \times 10^{2}$ & TMS \\
$\begin{array}{l}\text { Depot } \\
\text { Purwosari }\end{array}$ & $193 \times 10^{2}$ & $1,0 \times 10^{2}$ & TMS \\
\hline Standar & & & \\
\hline
\end{tabular}

Standar menurut SNI No.01-3553 tahun2006

Keterangan: TMS (Tidak Memenuhi Syarat)

MS (Memenuhi Syarat)

Tabel 3. Hasil Pengujian bakteri E.Coli pada sample air minum

\begin{tabular}{|c|c|c|c|}
\hline Sampel & E. Coli & Syarat & Ket \\
\hline Cleo & & $0 / 100 \mathrm{ml}$ & MS \\
\hline Le Mineral & & $0 / 100 \mathrm{ml}$ & MS \\
\hline VIT & & $0 / 100 \mathrm{ml}$ & MS \\
\hline Aqua & & $0 / 100 \mathrm{ml}$ & MS \\
\hline Airmu & & $0 / 100 \mathrm{ml}$ & MS \\
\hline Ades & & $0 / 100 \mathrm{ml}$ & MS \\
\hline Crystalin & & $0 / 100 \mathrm{ml}$ & MS \\
\hline $\begin{array}{l}\text { Depot } \\
\text { Pasuruhan }\end{array}$ & 1 & $0 / 100 \mathrm{ml}$ & TMS \\
\hline $\begin{array}{l}\text { Depot } \\
\text { Prambatan }\end{array}$ & 0 & $0 / 100 \mathrm{ml}$ & TMS \\
\hline $\begin{array}{l}\text { Depot } \\
\text { Purwosari }\end{array}$ & 3 & $0 / 100 \mathrm{ml}$ & TMS \\
\hline
\end{tabular}

Pengujian adanya kandungan bakteri E.Coli di dalam sampel menghasilkan angka nol pada 7 sampel AMDK dan 1 depot AMIU yaitu sampel depot air Prambatan, semua bebas kontaminasi bakteri E. Coli, sehingga memenuhi syarat untuk diminum, namun pada sampel 2 Depot AMIU tidak memenuhi persyaratan sebagai air minum karena terkontaminasi bakteri $E$.coli yaitu terdapat 1 koloni E. coli pada Depot Pasuruhan dan 3 koloni E. coli pada sampel Purwosari.Hasil diatasdimungkinkan kualitas pada saat pencucian galon untuk wadah air sample yang kurang hyginis hanya mengunakan sedikit tepol atau sabun cuci dan mesin pencuci galon yang sederhana dan terbuka sehingga memungkinkan adanya kontaminasi E. Coli. Bakteri E. coli adalah salah satu jenis spesies utama bakteri gram negative penyebab infeksi saluran pencernaan (Dufour, 1984). Sehingga dapat disimpulkan bahwa air minum isi ulang dari depot Pasuruhan dan Depot Purwosari tidak memenuhi syarat sesuai dengan Peraturan Menteri Kesehatan Republik Indonesia Nomor: 492/ Menkes/ per/IV/2010 tentang persyaratan air minum (PMK, 2010). Hal ini sesuai dengan penelitian Bambang (2014), yang menghasilkan 9 sampel air minum yang di uji mengandung cemaran mikroba yang berkisar antara $1,6 \mathrm{x} \quad 10^{3}$ sampai $2,9 \mathrm{x}$ $10^{4}$ koloni $/ \mathrm{mL}$.

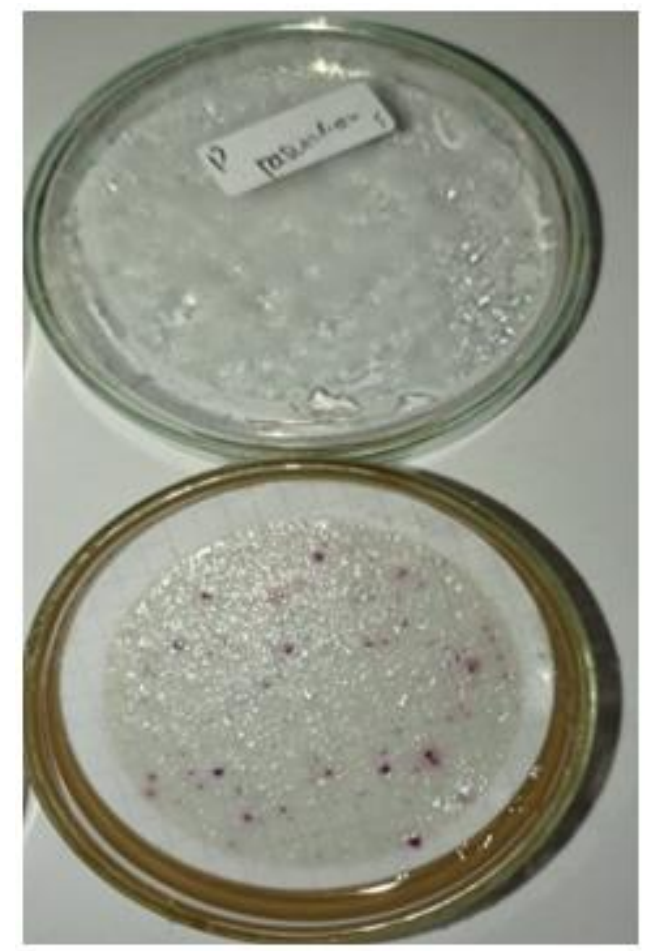

Gambar 2. Identifikasi Bakteri Escherichia coli depot air minum isi ulang Pasuruhan 
Tabel 4. Hasil Pengujian Total Coliform

\begin{tabular}{llll}
\hline Sampel & Coliform & Syarat & Ket \\
\hline Cleo & 0 & $50 / 100 \mathrm{ml}$ & MS \\
Le Mineral & 0 & $50 / 100 \mathrm{ml}$ & MS \\
VIT & 0 & $50 / 100 \mathrm{ml}$ & MS \\
Aqua & 0 & $50 / 100 \mathrm{ml}$ & MS \\
Airmu & 0 & $50 / 100 \mathrm{ml}$ & MS \\
Ades & 0 & $50 / 100 \mathrm{ml}$ & MS \\
$\begin{array}{l}\text { Crystalin } \\
\text { Depot }\end{array}$ & 0 & $50 / 100 \mathrm{ml}$ & MS \\
$\begin{array}{l}\text { Pasuruhan } \\
\text { Depot }\end{array}$ & 38 & $50 / 100 \mathrm{ml}$ & TMS \\
$\begin{array}{l}\text { Prambatan } \\
\text { Depot }\end{array}$ & TBUD & $50 / 100 \mathrm{ml}$ & MS \\
Purwosari & & $50 / 100 \mathrm{ml}$ & TMS \\
\hline
\end{tabular}

Bedasarkan tabel diatas tentang total coliform dari 7 sampel AMDK bebas dari kontaminan coliform sedangkan pada depot AMIU terdapat 38 MPN/100 ml dari Depot Prambatan hal ini masih dianggap memenuhi persyaratan, karena di bawah ambang batas persyaratan yaitu $50 / 100 \mathrm{ml}$. Namun pada sampel depot Prambatan terdapat 62 MPN/100 ml, dan TBUD pada depot Purwosari. Hasil di atas dimungkinkan kualitas pada saat pencucian galon dan juga segi operator atau penjual atau petugas pengisian air galon isi ulang yang tidak pernah pelatihan atau tidak mempunyai

\section{Daftar Pustaka}

Agustini, S. (2017). Harmonisasi Standar Nasional (SNI) Air Minum Dalam Kemasan Dan Standar Internasional (The Harmonization on the requirement of National Standard (SNI) Bottled Drinking Water Against to International standard. Majalah Teknologi Agro Industri (Tegi), 9(2), 30-39.

Bambang, Andrian G. (2014). Analisis cemaran bakteri coliform dan identifikasi Escherichia coli pada air isi ulang dari depot di Kota Manado. Pharmacon 3.3.

Conant, Jeff, and Pam Fadem. (2021). Panduan Masyarakat untuk ketrampilan (sofkill) tentang hygine dan sanitasi. Sehingga terdapat kontaminasi bakteri coliform. Coliform adalah golongan bakteri yang merupakan campuran antara bakteri fekal dan bakteri non fekal (Harmita dan Radji M, 2008). Hal ini membuktikan air isi ulang dari dua depot tersebut tidak laik minum karena di atas ambang batas persyaratan yaitu 50/100ml. Sehingga dua depot AMIU yaitu depot Pasuruhan dan depot Purwasari tidak memenuhi PMK No. 429 tahun 2010.

\section{Simpulan}

Dengan demikian penelitian ini dapat disimpulkan bahwa kualitas sama dari segi organoleptik, namun kualitas AMDK lebih baik AIMU dari segi mikrobiologi. Hasil membuktikan hasil TPC setelah pengenceran 7 sampel AMDK aman dan Layak sesuai SNI No.01-3553 tahun 2006 sebagai air minum langsung konsumsi. Namun hasil TPC, uji pengujiaan keberdaan E. Coli dan Total Coliform tidak menuhi Persyaratan sebagai air minum sesuai Peraturan Menteri Kesehatan Republik Indonesia Nomor: 492/ Menkes/per/IV/2010 tentang persyaratan air minum.

Kesehatan Lingkungan. Michosan Center Indonesia.

Departemen Kesehatan RI (2010). Peraturan Menteri Kesehatan RI Persyaratan Kualitas Air Minum. PERMENKES RI/NOMOR492/MENKES/PER/IV/2010.

Departemen Kesehatan Republik Indonesia. (2002). Syarat-Syarat Dan Pengawasan Kualitas Air Minum. PERMENKES NO. 907/MENKES/SK/VII/2002.

Deril, M., and Hendrasarie Novirina. (2014).

"Uji Parameter Air Minum Dalam Kemasan (AMDK) di Kota Surabaya." Envirotek: Jurnal Ilmiah Teknik Lingkungan 6.1: 1-6. 
Dufour, A.P. (1984). Health Effects Criteria for Fresh Recreational Waters. Cincinnati, Ohio, U.S. Environmental Protection Agency, EPA-600/1-84-004, 33p.

Ernawaningtyas, Endang, Yaya Sulthon Aziz, and Qoirul Adi Styawan. (2020). "Uji Cemaran Mikroba Air Minum Isi Ulang dari Depot Air Minum Di Wilayah Kabupaten Ponorogo. Medfarm: Jurnal Farmasi dan Kesehatan 9.1: 8-12.

Harmita dan Radji M. (2008). Buku Ajar Analisis Hayati, Edisi 3. Penerbit Buku Kedokteran EGC, Jakarta.

Mairizki, Fitri. (2017)."Analisa kualitas air minum isi ulang di sekitar kampus Universitas Islam Riau." Jurnal Katalisator 2.1: 9-19.

Mirza MN. (2014). Hubungan anatara Hygiene Sanitasi dengan Jumlah Coliform Air Minum pada Depot Air Minum Isi Ulang (DAMIU) di Kabupaten Demak tahun 2012. Unnes Journal of Public Health; 3 (2).

Parija, S.C., (2009), Textbook of Microbiology and Immunology, 71-73, Elsevier India Pvt. Ltd., India

Pratiwi, Astri Wulandari. (2014). Kualitas Bakteriologis Air Minum Isi Ulang di Wilayah Kota Bogor.

Rahayu, S. A., \& Gumilar, M. M. H. (2017). Uji cemaran air minum masyarakat sekitar margahayu raya bandung dengan identifikasi bakteri Escherichia coli. Indonesian Journal of Pharmaceutical Science and Technology, 4(2), 50-56.

Sekarwati, Novita, Subagiyono Subagiyono, and Hanifah Wulandari.(2016). "Total coliform dalam Air Bersih dan Escherichia coli dalam Air Minum pada Depot Air Minum Isi Ulang." Kes Mas: Jurnal Fakultas Kesehatan
Masyarakat 10.2: 49-56.

Subagiyono, Subagiyono, and Hanifah Wulandari. (2016). "Analisis Kandungan Bakteri Total Coliform dalam Air Bersih dan Escherechia Coli dalam Air Minum pada Depot Air Minum Isi Ulang di Wilayah Kerja Puskesmas Kalasan Sleman." Kes Mas: Jurnal Fakultas Kesehatan Masyarakat Universitas Ahmad Daulan 10.2: 1-12.

Sofa, Maya, and Widura Widura.(2010). "Kualitas Bakteriologis Air Minum dalam Kemasan "AC" yang tidak Terdaftar di Bandung." Maranatha Journal of Medicine and Health 1.2: 147816.

Wandrivel, Rido, Netty Suharti, and Yuniar Lestari. (2012). "Kualitas air minum yang diproduksi depot air minum isi ulang di Kecamatan Bungus Padang berdasarkan persyaratan mikrobiologi." JurnalKesehatan Andalas 1.3. 